\title{
Nutritional Awareness and Dietary Practices by Farm Women: An Empirical Study
}

\author{
Surabhi ${ }^{1 *}$ and Chandan Kumar Panda ${ }^{2}$
}

${ }^{1}$ Post Graduate Student (Former), Department of Sociology, Banasthali Vidyapith, Jaipur, Rajasthan, India

${ }^{2}$ Assistant Professor-cum-Junior Scientist, Dept. of Extension Education, Bihar Agricultural University, Sabour, India

"Corresponding author: ssurabhi124@gmail.com (ORCID ID: 0000-0002-7745-3425)

Received: $19-09-2020$

Revised: $27-11-2020$

Accepted: 04-12-2020

\begin{abstract}
Awareness on proper nutrition, nutritional value of food and healthy practices in food intake can build a difference in farm women productivity. Poor dietary practice is one of the biggest global contributing factors on recurrent disease in farm women. Negative effects of malnutrition among women were compounded by heavy farm work demands and poverty, although technological breakthrough brought tremendous scope in agriculture sector. Under this backdrop, this study was conducted with the objectives to gauge the nutritional awareness and dietary practices by farm women. The study was conducted among 150 farm women of Bhagalpur district of Bihar. From this research, it can be concluded that mass media, social media, and grassroots extension functionaries play pivotal role in creation of nutritional awareness among farm women. The mostly dietary practices included cereals (Rice, Wheat \& Maize) and farm women nutritional awareness is significantly correlated with age, education level and mass media exposure of farm women.

Highlights

( Assure nutritional support safeguard farm women from number of diseases and ensure farm women productivity.

0 Nutritional awareness and its practice by farm women are correlated. It was noted that that mass media, social media, and grassroots extension functionaries play pivotal role in creation of nutritional awareness among farm women.
\end{abstract}

Keywords: Farm women, nutrition, diet, cereal, education level

Awareness on proper nutrition, nutritional value of food and healthy practices in food intake can build a difference in healthy society and nation as a whole. Deficiencies in nutritional practices may lead to unproductive life in farm women. Poor dietary practice is one of the biggest global contributing factors on recurrent disease. Human body derives strengthen and protection against disease through the intake of balance diet. In Indian farming, farm women immensely contribute in food production, however, nutritional status as well as nutritional knowledge of women were unsatisfactory and needs interventions (Upadhyay et al. 2011). Actually, negative effects of malnutrition among women were compounded by heavy work demands and poverty (Jethi and Chandra, 2016), although technological breakthrough brought tremendous scope in agriculture sector (Panda and Bhatnagar, 2020). Hence, the nutrition education about the importance of balanced diet, food groups and their functions and eat right according to body requirements and working status (Jyoshna et al. 2017) need to be cater among to the farm women through different media

How to cite this article: Surabhi and Panda, C.K. (2020). Nutritional Awareness and Dietary Practices by Farm Women: An Empirical Study. Economic Affairs, 65(4): 575-580.

Source of Support: None; Conflict of Interest: None (क) 
as associated with farm technology dissemination (Panda, 2014). Farm women extent of knowledge in relation to nutrition was low, however, it could be improves through nutrition training programme (Kumar et al. 2016). Farm women performed agricultural activities and household activities however, their dietary, nutritional and energy intake was lower (Singh et al. 2012).

\section{MATERIALS AND METHODS}

The study was conducted in Bhagalpur district of Bihar. Farm women were selected randomly from three blocks of the district namely, Sabour, Naugachhia and Pirpainti. From each block 50 farm women were selected randomly. Hence the sample size were 150. The Questionnaire was pretested over 15 number of farm women. Although questionnaire were prepared in English language, but during interview it was translated to local language i.e. Hindi. Data was collected during September, 2019 to December, 2019. The schedule was developed for the study, however, Nutritional Awareness of the farm women was tested through the scale developed by van Dillen et al. (2008). The statistical methods administered were mean, per cent, Standard Deviation, Rank and correlation coefficient. For analysis of data IBM SPSS 21 was employed.

\section{RESULTS AND DISCUSSION}

It is imperative to know the situational context of farm women; hence socio-economic profile of farm women was studied. From the table 1, it is noted that 32 per cent farm women belong to 50-60 years age group, however 8 per cent respondent belonged to upto 30 years age group. The perusal of table also revealed that education level of 60 per cent farm women was up to $5^{\text {th }}$ standard and only 2 per cent up to higher secondary. It is also noted that 80 per cent respondent had up to 1hectare land and most of them belonged to nuclear family (56.67\%). Amongst the respondent 60 per cent were non vegetarian and 40 per cent were vegetarian and 34 per cent respondent's farming experience range between 20-30 years.

Farm women consumed different type of food items, so it is essential to know their categories of nutritional sources and their diet pattern. It is noted that 56.67 per cent respondent's nutritional source was cereals (rice, wheat and maize) with home production, however 21.33 percent purchased the same from the market and 50 per cent of the respondent got the same through home production and purchasing from the market. It is also noted that 60 per cent respondent purchased animals protein

Table 1: Socio-economic Profile of Farm Women $(n=150)$

\begin{tabular}{|c|c|c|c|c|c|c|c|c|c|}
\hline Variables & Class interval & Fr & $\%$ & Mean & SD & CV(\%) & Mode & Min. & $\operatorname{Max}$ \\
\hline \multirow{6}{*}{ Age (in Year) } & Up to 30 & 12 & 8.00 & & & & & & \\
\hline & 30 to 40 & 39 & 26.00 & 43.20 & 12.94 & 27.95 & 52 & 28 & 65 \\
\hline & 40 to 50 & 27 & 18.00 & & & & & & \\
\hline & 50 to 60 & 48 & 32.00 & & & & & & \\
\hline & $>60$ & 24 & 16.00 & & & & & & \\
\hline & Up to $5^{\text {th }}$ Std. & 90 & 60.00 & & & & & & \\
\hline \multirow{2}{*}{ Land Holding (in Ha) } & Upto 1 ha & 120 & 80.00 & .63 & .46 & 71.05 & .32 & .16 & 2.32 \\
\hline & $>1$ ha & 30 & 20.00 & & & & & & \\
\hline \multirow{3}{*}{ Family Size } & Up to 4 & 60 & 40.00 & & & & & & \\
\hline & 4 to 6 & 63 & 42.00 & & & & & & \\
\hline & $>6$ & 27 & 18.00 & & & & & & \\
\hline Types of Diet & Non-Vegetarian & 90 & 60.00 & & & & & & \\
\hline \multirow{5}{*}{ Farming Experience (in Years) ${ }^{f}$} & Up to 10 & 18 & 12.00 & & & & & & \\
\hline & 10 to 20 & 45 & 30.00 & & & & & & \\
\hline & 20 to 30 & 51 & 34.00 & 22.34 & 10.17 & 47.52 & 25 & 5 & 50 \\
\hline & 30 to 40 & 27 & 18.00 & & & & & & \\
\hline & $>40$ & 9 & 6.00 & & & & & & \\
\hline
\end{tabular}


Table 2: Nutritional Sources of Farm Women $(n=150)$

\begin{tabular}{lllll}
\hline \multirow{2}{*}{ S1. No. } & Nutritional Items & \multicolumn{3}{c}{ Sources } \\
\cline { 3 - 5 } & & $\begin{array}{l}\text { Home Production } \\
\text { (A) }\end{array}$ & $\begin{array}{l}\text { Purchase from } \\
\text { market (B) }\end{array}$ & Both A \& B \\
\hline 1 & Cereals(Rice, Wheat \& Maize) & $85(56.67 \%)$ & $32(21.33 \%)$ & $75(50 \%)$ \\
2 & Animals Protein (Egg, Fish, Meat) & $12(8.00 \%)$ & $90(60.00 \%)$ & $8(5.33 \%)$ \\
3 & Plants Protein (Pulses-Moong, Arhar, Lentil, Gram) & $64(42.67 \%)$ & $70(46.67 \%)$ & $52(34.67 \%)$ \\
4 & Fat (Different Oils) & $32(21.33 \%)$ & $89(59.33 \%)$ & $15(10.00 \%)$ \\
\hline
\end{tabular}

Figure in the () indicate \%. Multiple Response.

Table 3: Mass Media and Extension Personal Exposure of Farm Women $(n=150)$

\begin{tabular}{lllllll}
\hline S1. No. & Mass Media & Most Often & Sometimes & Rarely & Weighted Mean & Rank \\
\hline 1 & Television & $38(25.33 \%)$ & $82(54.67 \%)$ & $30(20.00 \%)$ & 2.05 & IV \\
2 & Social Media & $23(15.33 \%)$ & $78(52.00 \%)$ & $49(32.67 \%)$ & 1.82 & V \\
3 & Newspaper & $10(6.67 \%)$ & $20(13.33 \%)$ & $120(80.00 \%)$ & 1.27 & VII \\
& Awareness campaign & $25(16.67 \%)$ & $60(40.00 \%)$ & $65(43.33 \%)$ & 1.73 & VI \\
4 & ICDS Workers & $73(48.67 \%)$ & $40(26.77 \%)$ & $37(24.66 \%)$ & 2.24 & II \\
5 & Rural Health Workers & $65(43.33 \%)$ & $68(45.33 \%)$ & $17(11.34 \%)$ & 2.32 & I \\
6 & Primary Health Centre workers & $58(38.67 \%)$ & $69(46.00 \%)$ & $23(15.33 \%)$ & 2.23 & III \\
\hline
\end{tabular}

(egg, fish and meat) from the market. Only 8 per cent of them had their home production. In case of plants protein (pulses- Moong, Arhar, Lentils and Gram), it was observed that 46.6 per cent respondent purchased the same from the market while 34.67 per cent farm women obtained it through home production and purchased from market (table 2).

In present context mass media, social media, grassroots extension functionaries play pivotal role in dissemination of nutritional related information among the common people. However, it becomes imperative to know the roles of these Media in nutrition awareness creation among the farm women. It is noted that rural health workers contributed mostly on creation of nutritional awareness among the farm women and it was ranked I followed by ICDS workers (rank-II), Primary health centre workers (rank III) and television (rank-IV) (table 3).

The nutritional awareness of farm women was assessed based on a scale (Dillen et al. 2008). The perusal of table 4 revealed that major nutritional awareness factors were Take care that eat regularly (rank I), do not want to ask things eat are good one (rank II), do not worry about healthiness of food (rank III), healthiness snacks makes no difference (rank IV) and take care on balance diet (rank V).

It is noted that 100 per cent farm women took cereals, pulses and legume, vegetables and fat.
However, it is noted that 25.33 per cent farm women took fruits (table 5). The perusal of table 6 revealed that 71.33 per cent farm women took leafy vegetables daily, 88.67 per cent received tuber and root daily however 50.67 per cent farm women consumed beans weekly and 40.67 percent took nuts (Groundnut, Cashew nut) monthly. However, consumption of animal Protein i.e. Meat, Fish and Egg were mostly monthly basis.

Knowledge Gap of farm women on foods nutritional value and importance were assessed and it is noted that 40.00 per cent farm women knowledge gap varies between 40- 60 per cent. However, 11.33 per centre respondent knowledge gap arranged between 80- 100 per cent (table 7). Physical Parameters of respondents were also assessed and it was found that average Body Mass Index $\left(\left(\mathrm{kg} / \mathrm{m}^{2}\right)\right.$ of farm women was 21.78 (table 7).

Correlation coefficient between farm women's degree of nutritional awareness and situational variables were studied, it was observed that nutritional awareness was positively and significantly correlated with age, education level, mass media exposure. From this relationship it may be inferred that as the age, educational level and social media exposure increases so the respondent nutritional awareness will increase. However, it is observed that nutritional awareness is negatively and significantly correlated with body mass index. 
Table 4: Nutritional Awareness of Farm Women ( $\mathrm{n}=150)$

\begin{tabular}{llll}
\hline S1. No. & Items & Weighted Mean & Rank \\
\hline 1 & Take care that eat regularly & I \\
2 & Do not want to ask oneself all the time whether the things eat are good for one & 4.12 & II \\
3 & Eat what like and do not worry much about the healthiness of food & 4.04 & III \\
4 & The healthiness of snacks makes no difference & 3.89 & IV \\
5 & Take care on balanced diet & 3.89 & V \\
6 & It is important that diet should be low in fat & 3.87 & VI \\
7 & It is important to eat two pieces of fruit and 200 g of vegetables a day & 3.87 & VII \\
8 & Very particular about the healthiness of food eat & 3.45 & VIII \\
9 & It is important that daily diet contains a lot of vitamins and minerals & 3.41 & IX \\
10 & Prepared to leave a lot, to eat as healthy as possible & 3.34 & X \\
11 & Have the impression that other people pay more attention to healthy eating & 3.32 & XI \\
12 & Healthiness of food has little impact on food choices & 3.31 & XII \\
13 & Do not avoid foods, even if they may raise cholesterol & 2.98 & XIII \\
14 & It is important to know how to eat healthy & 2.98 & XIV \\
15 & Pay attention that do not eat too much & 2.87 & XV \\
16 & Pay attention to food that do not use too much sugar & 2.87 & XVI \\
17 & Always follow a healthy and balanced diet & 2.78 & XVII \\
\hline
\end{tabular}

Table 5: Food items intake by Farm Women $(\mathrm{n}=150)$

\begin{tabular}{|c|c|c|c|c|}
\hline S1. No. & \multicolumn{2}{|l|}{ Food items } & Frequency & Per cent $(\%)$ \\
\hline 1 & \multicolumn{2}{|l|}{ Cereals } & 150 & 100 \\
\hline 2 & \multicolumn{2}{|c|}{ Pulses and legumes } & 150 & 100 \\
\hline \multirow[t]{4}{*}{3} & \multirow[t]{4}{*}{ Vegetables - } & Leafy vegetables & 150 & 100 \\
\hline & & Tubers \& Roots & 143 & 95.33 \\
\hline & & Beams & 128 & 85.33 \\
\hline & & Others Vegetables & 143 & 95.33 \\
\hline 4 & \multicolumn{2}{|c|}{ Nuts (Groundnut, Cashew nut) } & 80 & 53.33 \\
\hline 5 & \multicolumn{2}{|c|}{ Fats \& oils } & 150 & 100 \\
\hline 6 & \multicolumn{2}{|c|}{ Milk and its products } & 85 & 56.67 \\
\hline 7 & \multicolumn{2}{|c|}{ Animal Protein (Fish, Egg, Meat ) } & 76 & 50.67 \\
\hline 8 & \multicolumn{2}{|c|}{ Fruits } & 38 & 25.33 \\
\hline
\end{tabular}

Table 6: Frequency of Intakes as influenced by diet types $(n=150)$

\begin{tabular}{llllllll}
\hline $\begin{array}{l}\text { S1. } \\
\text { No. }\end{array}$ & Food items & Daily & Weekly & Monthly & $\begin{array}{l}\text { Chi-square } \\
\text { (observed value) }\end{array}$ & $\begin{array}{l}\text { Chi-square } \\
\text { (critical value) }\end{array}$ & P-Value \\
\hline 1 & Cereals & $150(100 \%)$ & 0 & 0 & 1.623 & 5.871 & $0.490^{N S}$ \\
2 & Pulses \& Legumes & $135(90 \%)$ & $15(10 \%)$ & 0 & 4.499 & 5.859 & $0.105^{N S}$ \\
3 & Leafy vegetables & $107(71.33 \%)$ & $43(28.67 \%)$ & 0 & 1.631 & 5.789 & $0.432^{N S}$ \\
4 & Tubers \& Roots & $133(88.67 \%)$ & $10(6.67 \%)$ & 0 & 0.457 & 3.631 & $0.389^{N S}$ \\
& (Vegetable) & & & & & & \\
5 & Beans(Vegetable) & $34(22.67 \%)$ & $76(50.67 \%)$ & $40(26.66 \%)$ & 1.323 & 3.573 & $0.390^{N S}$ \\
6 & Nuts (Groundnut, & $7(4.67 \%)$ & $12(8.00 \%)$ & $61(40.67 \%)$ & 2.479 & 4.754 & $0.095^{N S}$ \\
& Cashew nut) & & & & & & $0.322^{N S}$ \\
7 & Milk & $89(59.33 \%)$ & $43(28.67 \%)$ & $18(12.00 \%)$ & 1.781 & 5.595 & $0.239^{N S}$ \\
8 & Meat & $0(\%)$ & $15(10.00 \%)$ & $25(16.67 \%)$ & 0.357 & 3.231 & $0.490^{N S}$ \\
9 & Fish & $12(8.00 \%)$ & $25(16.67 \%)$ & $32(21.33 \%)$ & 1.421 & 5.871 & $0.125^{N S}$ \\
10 & Egg & $5(3.33 \%)$ & $32(21.33 \%)$ & $34(22.67 \%)$ & 3.299 & 4.879 & $0.115^{N S}$ \\
11 & Fruits & 0 & $57(38.00 \%)$ & $43(28.67 \%)$ & 1.379 & 4.654 & \\
\hline
\end{tabular}


Table 7: Knowledge gap of farm women on foods nutritional value and importance $(n=150)$

\begin{tabular}{llll}
\hline Sl. No. & Knowledge Gap Level & Frequency & Per cent \\
\hline 1 & Upto $20 \%$ & 21 & 14.00 \\
2 & $>20 \%$ to $\leq 40 \%$ & 29 & 19.33 \\
3 & $>40 \%$ to $\leq 60 \%$ & 60 & 40.00 \\
4 & $>60 \%$ to $\leq 80 \%$ & 23 & 15.33 \\
5 & $>80 \%$ to $\leq 100 \%$ & 17 & 11.33 \\
\hline
\end{tabular}

Table 8: Physical Parameters of Farm Women $(n=150)$

\begin{tabular}{lll}
\hline S1. No. & Particulars & Average \\
\hline 1 & Height $(\mathrm{cm})$ & 153.45 \\
2 & Weight $(\mathrm{kg})$ & 53.20 \\
3 & Body Mass Index $\left(\mathrm{kg} / \mathrm{m}^{2}\right)$ & 21.78 \\
\hline
\end{tabular}

Table 9: Correlation Coefficient between degree of nutritional awareness and situational variables ( $\mathrm{n}=150)$

\begin{tabular}{lll}
\hline Sl. No. & Parameter & Correlation Coefficient $(\mathrm{r})$ \\
\hline 1 & Age $\left(\mathrm{X}_{1}\right)$ & $0.267^{*}$ \\
2 & Education level $\left(\mathrm{X}_{2}\right)$ & $0.321^{* *}$ \\
3 & Mass Media Exposure $\left(\mathrm{X}_{3}\right)$ & $0.284^{*}$ \\
4 & Social Media Exposure $\left(\mathrm{X}_{4}\right)$ & 0.189 \\
5 & Family Size $\left(\mathrm{X}_{5}\right)$ & 0.129 \\
6 & Body Mass Index $\left(\mathrm{kg} / \mathrm{m}^{2}\right)\left(\mathrm{X}_{6}\right)$ & $-0.246^{*}$ \\
\hline
\end{tabular}

*Significant at $5 \%$ level. ${ }^{*}$ Significant at $1 \%$ level.

From this negative relationship, it may be concluded that higher the body mass index i.e. body weight lowers the level of nutritional awareness among the farm women (table 9).

\section{CONCLUSION}

Farm women immensely contribute in farming, however, poor dietary practice by them is one of the biggest global contributing factors on their recurrent disease. Negative effects of malnutrition among women were compounded by heavy farm work demands and poverty, although technological breakthrough brought tremendous scope in agriculture sector. From the study it is concluded that mass Media, social Media, and grassroots extension functionaries are creating the nutritional awareness among farm women. Although, farm women independent on availability of cereals (rice, wheat and maize) and to moderate extend on vegetables and pulses, however, for getting animal proteins (fish, meats, eggs), mostly, they have to depend on external sources i.e. have to purchase from the market. Major nutritional awareness factors among farm women were (a) take care that eat regularly and (b) take care on balance diet. There is Knowledge Gap of farm women on foods nutritional value and importance, so training and awareness programme may be conducted on regular basis. Farm women nutritional awareness is significantly correlated with age, education level and mass media exposure of farm women.

\section{REFERENCES}

Jethi, R. and Chandra, N. 2016. Nutritional status of farm women in hills of Uttarakhand. Indian Research Journal of Extension Education, 13(3): 92-97.

Jyoshna, E., Kumar, J.H., Kumar, N.K. and Reddy, P. 2017. Impact of nutritional education on nutritional status and work participation of farm women in Khammam district. Journal of Pharmacognosy and Phytochemistry, 6(4): 48-51.

Kumari, M., Srivastava, A.K. and Sinha, N. 2016. Extent of knowledge of farm women on nutrition. Indian Research Journal of Extension Education, 10(1): 65-68.

Panda, C.K. 2014. Information Sources and Technology Adoption by Farmers: An Empirical study in Mohanpur Block, West Tripura. International Journal of Extension Education, 10: 80-87.

Panda, C.K. and Bhatnagar, R. 2020. Social internet of things in agriculture: an overview and future scope. In Panda $\mathrm{Ck}$ and Bhatnagar R(ed) Toward Social Internet of Things (SIoT): Enabling Technologies, Architectures and Applications. Springer, Cham. 
Singh, S., Sinwal, S. and Rathore, H. 2012. Assessment of energy balance of Indian farm women in relation to their nutritional profile in lean and peak agricultural seasons. Work, 41(Supplement 1): 4363-4371.

Upadhyay, S., Kumar, A.R., Raghuvanshi, R.S. and Singh, B.B. 2011. Nutritional status and knowledge of hill women on anemia: Effect of various socio-demographic factors. Journal of Human Ecology, 33(1): 29-34. van Dillen, S.M., Hiddink, G.J., Koelen, M.A., de Graaf, C. and van Woerkum, C.M. 2008. Exploration of possible correlates of nutrition awareness and the relationship with nutrition-related behaviours: results of a consumer study. Public Health Nutrition, 11(5): 478-485. 